\title{
Change of Surface Charge of Moringa olifera Seeds Powder and their Effects on Protein Binding Lead (II)
}

\author{
Sherif S. Saleh ${ }^{1}$, Nahed S. A. El-Shayeb ${ }^{1}$, Adel F. Ahmed ${ }^{1}$ and Ahmed H. Ibrahim ${ }^{2}$ \\ ${ }^{I}$ Medicinal and Aromatic Plants Researches Dept., Horticulture Research Institute, Agricultural \\ Research Center, Egypt \\ ${ }^{2}$ Faculty of Science, Physical chemistry Dept. Al Azhar University, Egypt
}

Received: 10 Feb. 2020 / Accepted 15 April 2020 / Publication date: 30 April. 2020

\begin{abstract}
The drinking water needs to be treated in order to remove impurities and bacteria to meet the quality guidelines which satisfy 5 nephelometric turbidity units (NTU) for drinking water requirement according to World Health Organization. In this study we conducted to use coagulation method to remove the heavy metal (lead ions) from synthetic waste water by using various $\mathrm{pH}(2,4,6$ and 8$)$ and concentration of lead $(0.5,1.0$ and $1.5 \mathrm{~g} / \mathrm{l})$ during coagulation periods (1,2 and 3 days). At the end of coagulation periods, turbidity, total participant protein and quantity of heavy metals in clarified water was determined against distilled water as control. Moringa oleifera as coagulant reduced the initial amount of lead in clarifying water $\mathrm{pH} 6$ to 0.097 (ug) optimum dosage of $1.5 \mathrm{~g} \mathrm{~L}^{-1}$ after 3 days. The treatment efficiency of Moringa oleifera as a coagulant matter with using $\mathrm{pH} 6$ after three days gave $93.509 \%$ of protein binding lead. Thus, in the light of this study, an establishment of a cheaper and safer coagulant such as Moringa oleifera seed to treat the problems that rises due to the usage of aluminum sulphate such as health implications for rural areas usage can be established.
\end{abstract}

Keywords: Moringa oleifera, Heavy metals, Coagulating protein, waste water

\section{Introduction}

Through unsafe and unhealthy drinking water or unhealthy foods can spread diseases and epidemics. Globally such infections cause more than 1.8 million of mortality every year and among which $88 \%$ of the cases are attributable to consumption of unhygienic water (Reddy et al., 2017). Biohazardous and non-degradable geotaxis compounds of chemical/mineral waste released by the pharmaceuticals, leather and textile industries, etc. contribute to high degree of waterborne infections initiating adverse ecological effects to human and animals (Adelaja et al.,2011). Such physiological adverse health effects lead, not only impending to risks like reproductive impairment, cancers and neurological disorders, but also helps in spreading the multidrug resistant bacteria in drinking (Figueira et al., 2011; Taylor et al., 2011) and surface waters (Masters et al., 2011).Though it becomes the priority to provide 'safe drinking water' the technology exists today and is much debated due to the usage of chemicals like aluminum sulfate $\mathrm{Al}_{2}\left(\mathrm{SO}_{4}\right)_{3}$ (Guo et al., 2015), Ozone, Chlorine and Permanganate ( $\mathrm{Li}$ et al., 2018), ferric sulfate and polyaluminum chloride (Liang et al., 2019), polyethylene terephthalate (PET) (Jabłońska, 2018), etc. that indirectly contributes to several serious health problems on prolonged usage (Guo et al., 2015; Li et al., 2018; Liang et al., 2019; Jabłońska, 2018).

Study of water bodies and wastewater treatment plants reveal that some water quality parameters including heavy metals exceed the World Health Organization (WHO, 2012), acceptable limits. Egypt is the most populated country in the Middle East and its capital, Cairo, is one of the world's megacities. Greater Cairo (Cairo, Giza and Qalyubia and their urban agglomeration) is home to almost 20 million residents and hosts various industrial complexes that may emit $\mathrm{Pb}$ to the surrounding environment.

Our recent quality inventory compilation of wastewater treatment plants (Al-Omranya and Zenin) recorded levels of lead from 0.027 to $0.118 \mathrm{mg} / \mathrm{L}$ with most values exceeding the WHO limit. Lead is a pollutant of global concern with well-known toxic effects. Major sources of lead pollution in water are lead-acid batteries, lead pipes, solders, agricultural chemicals, lead mining, and vehicle exhausts especially. Lead is a power fulneurotoxin and a range of pathological conditions is associated with acute lead poisoning, the most characteristic being cerebral edema. Clean-up technologies for the removal of

Corresponding Author: Sherif S. Saleh, Medicinal and Aromatic Plants Researches Dept. Horticulture Research Institute, Agricultural Research Center, Egypt.

E-mail: Sherif_Saied_Saleh@yahoo.com 
lead ions and other heavy metals from water include chemical coagulationusing ferric chloride $\left(\mathrm{FeCl}_{3}\right)$ or the biopolymer Floculan (Andrew et al., 2015) and surfactants (Kongarapu et al., 2018); ion exchange and adsorption (Fu and Huang, 2018) and phytoremediation (Chang et al., 2019) that includes rhizofiltration, phytostabilization and phytoextraction.

Coagulation-flocculation followed by sedimentation, filtration and disinfection is used worldwide in the water treatment industry. The Moringa oleifera is from the family of the Moringaceae and it has been naturalized in the subtropical as well as tropical areas around the world such as Asia, South America, Africa and the Pacific as well as Caribbean Islands (Abdull et al., 2014). Moringa oleifera seeds have been used as a coagulant for purifying water (Shan et al., 2017), for instance Carvalho et al., (2015) studied the efficiency of seeds for the removal of acid black 1 and basic red 2. Jafari et al., (2015) and Santos et al., (2016) examined the ability of seeds in the removal of reactive dyes. Reck et al. (2018) did the similar studies for identifying the potential of seeds to remove atrazine. Besides, several other studies have been done using the seeds in order to remove heavy metals from the aqueous media (Khorsand et al., 2017) and removal of organic pollutants from aqueous solutions (Obuseng et al., 2012) . However, the pods of seeds are usually regarded as useless. There are few studies reporting the use of Moringa oleifera pods as sorbent for removing the organics such as benzene and ethylbenzene (Akhtar et al., 2007), atrazine (Coldebella et al., 2017) and heavy metals such as lead (Tavares et al., 2017) , cadmium, copper, manganese, iron, zinc, and magnesium (Maina et al., 2016) because of being inexpensive and effective in pollutants removal. However, in most of the previous studies (Déborah et al., 2018) same types of pollutants were studied (either metals or dyes) with no comparison between different types of pollutants (such as metals and dyes). Moreover, most of the studies were limited to batch-scale only.

\section{Materials and Methods}

\section{Materials}

Synthetic wastewater solutions were prepared by dissolving a desired amount of lead acetate (g) of analytical grade in distilled water to obtain stock solution. All the chemicals used were of analytical grade. Distilled water was used throughout the experiments.

\section{Source of coagulation proteins}

M. olifera seeds was obtained from Al Qalyobia Farm (Medicinal and Aromatic Dept., Horticulture Res. Institute, A.R.C., Egypt) December in 2016. The seeds were identified by the Horticulture Research Institute of Egypt. Seeds was de-shelled by hand and then grounded in a domesticblender and sieved through $0.08 \mathrm{~mm}$ stainless steel sieve.one gram of MOS powder was added to $100 \mathrm{ml}$ distilled water and stirred $200 \mathrm{rpm}$ for 15 minutes using magnetic stirrer to create active constituents to prepare stoke solution of $100 \mathrm{mg} / \mathrm{L}$.

\section{Instrumentation}

The $\mathrm{pH}$ of the solution was determined using a HANNA instruments $\mathrm{pH}$ meter ( $\mathrm{pH} 209$ models, Portugal). Jeol (Tokyo,japan) JSM 5600 LV (Egypt Nanotechnology Center, Cairo University, Shaikh Zayed Campus, B3). The surface morphology was studied using a Jeol(Tokyo,japan) JSM 5600 LV. Oxford instruments 6587 EDX micro-analysis detector EDX micro-analysis was made to obtain information on the elemental composition of the sample (Egypt Nanotechnology Center, Cairo University, Shaikh Zayed Campus, B3). A micromeritics (Novatouch LX2, Quantachrome Instruments, Boynton Beach, Florida, USA (Egypt Nanotechnology Center, Cairo University, Shaikh Zayed Campus, B3 instrument) was used for Brunau-Emmett-Teller (BET) analysis to determine information such as surface area, total pore volume, and average pore size of Moringa seed powder. In a BET surface area analysis, a dry sample was evacuated of all gas and cooled to $77 \mathrm{~K}$ using liquid nitrogen.

\section{Coagulation technique}

To make wastewater using distilled water by adding lead acetate at $0.5,1.0$ and $1.5 \mathrm{~g} / \mathrm{l}$ plus free distilled water as control A weight of $0.5,1.0$ and $1.5 \mathrm{gm}$ of Lead acetate then filtrated by Whattman No.1 filter paper, laboratory grade (K7375, particle size 0.1-4 $\mu \mathrm{m}$, Sigma-Aldrich), was dissolved with $1000 \mathrm{ml}$ of distilled water. All experiments were performed at room temperature $\left(25^{\circ} \mathrm{C} \pm 1^{\circ} \mathrm{C}\right)$. The 
sample mixed with the MOS stock of required dosage and mixed by shaker for three minutes. the samples was centrifuged by (ROTOFIX 32-HETTICH) at $5000 \mathrm{rpm}$ for 5 minutes .then determine the concentration of $\mathrm{Pb}$ ions, turbidity and total protein in filtrate but determination of sediment weight in precipitate.

\section{Charge by pH}

All $\mathrm{pH}$ measurements were determined using a pH meter (pH 209 models, Portugal) calibrated with buffers at $\mathrm{pH} 4$ and 7 . Lead solutions of different $\mathrm{pH}(2,4,6$ and 8) were prepared by adjusting the $\mathrm{pH}$ of a $100 \mathrm{ml}$ solution of MOS using $0.1 \mathrm{~N}$ sodium hydroxide or $0.1 \mathrm{~N}$ hydrochloric acid.

\section{Effect of coagulation time}

The effects of contact time on coagulation process were studied in the time ranges from 1 to 3 days with different initial lead ion concentrations as well as $\mathrm{pH}$ values.

\section{Effects of initial lead (II) concentration}

$2 \mathrm{ml}$ of $0.5,1.0$ and $1.5 \mathrm{~g} / \mathrm{l}$ of aqueous lead solution was added to $2 \mathrm{ml}$ of $1.0 \%$ of MOS stock. The aliquots were stirred and withdrawn at different time intervals, and centrifuged. The residual concentration was quantified using EDTA complexmetric titration method according to Malati (1999).

\section{Protein electrophoresis}

Sodium dodecyl sulfate (SDS) - polyacrylamide gel electrophoresis was performed in $12 \%$ acrylamide slab gels following the system of Laemmli, (1970) to identify the protein profiles of plant samples.

\section{Data and parameters}

\section{Sedimentation rate calculation}

The sedimentation method basically depending on weight of the sediment in the plasticWither man test tube at the end and before of coagulation period (initial weight $\mathrm{W}_{\mathrm{i}}$ ). The sediment was dried in the oven at $40 \mathrm{C}$ for two hours and then weighted (final weight). The sedimentation rate was calculated relatively for coagulation period as shown:

Sedimentrate $=\Delta \mathrm{W} / \Delta \mathrm{t}=\left(\mathrm{W}_{\mathrm{f}}-\mathrm{W}_{\mathrm{i}}\right) / \mathrm{t}=\mathrm{mg} / \mathrm{day}$.

Sediment factor $(K)$ : wat $\quad \mathrm{w}=K \mathrm{t} \quad \mathrm{k}=\mathrm{w} / \mathrm{t} \quad K=\Delta \mathrm{W} / \Delta \mathrm{t}$

Where $\mathrm{W}_{\mathrm{f}}$ is the final weight $-\mathrm{W}_{\mathrm{i}}$ is the initial weight at the end of first day $-\mathrm{t}$ time of coagulation $-K$ is sedimentation factor (Robbins, 1973).

\section{Turbidity}

Turbidity was measured with a 2100P turbidimeter from Hach. The initial turbidity was measured 3 times on the raw water while stirring, and the average value from the three measurements was used as a starting value. After the sedimentation phase, samples for turbidity measurement were collected from the supernatant using a standard pipette. The sample beaker was washed once with distilled water and twice with the supernatant before recording the turbidity. Each measurement took 1-2 minutes, washing included, thus the last jar to be measured upon had in fact been sedimenting for up to 40 minutes. In order to eliminate any differences in turbidity due to different sedimentation times.

\section{Statistical analysis}

Data obtained were recorded and were exposed to the proper statistical analysis of complete randomized design block (Steel and Torrie, 1980) in three replicates. Means obtained were differentiated using Duncan's new multiple range test as described by (Duncan, 1955). 


\section{Results}

\section{Coagulation factors}

\section{Effect of pH}

The data in Table (1) and Fig. (1) showed that the effect of $\mathrm{pH}$ on precipitate of lead during three days of clarification period. After adding seeds powder to synthetic wastewater containing $0.5 \mathrm{~g} / \mathrm{Pb}$ and change of the $\mathrm{pH}$ values to 2, 4, 6 and 8 , in all cases the removal lead increased to the maximum values at $\mathrm{pH} 6$ and then decreased at $\mathrm{pH} 8$.

The synthetic wastewater containing lead at $500 \mathrm{mg} / \mathrm{l}$ was precipitate to $12.55,68.77,75.23 \%$ at $\mathrm{pH} 2,4$ and 6, respectively. At the final, at pH 8 the removal percentage decreased to $47.42 \%$. The same results on the second day of clarification raw water at the same level of lead $(0.5 \mathrm{~g} / \mathrm{l})$ it was scored $28.81,62.96,71.41 \%$ and decreased to $50.85 \%$ at $\mathrm{pH} 8$. At the last daythe starting removal lead was $7.32,65.09,66.78 \%$ and $63.79 \%$, respectively. Similarly, the coagulation process was increase gradually at from $\mathrm{pH} 2$ to $\mathrm{pH} 6$ to score the maximum level of removal percentage $93.50 \%$ for $1.5 \mathrm{~g} / 1$ $\mathrm{Pb}$ after three days incubation.

Table 1: Effect of various $\mathrm{pH}$ on clarification synthetic raw water, removal heavy metal and reduction turbidity by using Moringa oliefera seeds powder

\begin{tabular}{|c|c|c|c|c|c|c|c|c|c|c|c|c|}
\hline \multirow[b]{2}{*}{ pH 2} & \multicolumn{4}{|c|}{ Heavy metal (ug) } & \multicolumn{4}{|c|}{ Coagulation } & \multicolumn{4}{|c|}{ \% Reduction Turbidity } \\
\hline & $\begin{array}{c}1 \\
\text { day }\end{array}$ & $\begin{array}{c}2 \\
\text { days }\end{array}$ & $\begin{array}{c}3 \\
\text { days }\end{array}$ & Mean & $\begin{array}{c}1 \\
\text { day }\end{array}$ & $\begin{array}{c}2 \\
\text { days }\end{array}$ & $\begin{array}{c}3 \\
\text { days }\end{array}$ & Mean & $\begin{array}{c}1 \\
\text { day }\end{array}$ & $\begin{array}{c}2 \\
\text { days }\end{array}$ & $\begin{array}{c}3 \\
\text { days }\end{array}$ & Mean \\
\hline Pb $0.5 \mathrm{~g} / \mathrm{l}$ & 0.44 & 0.36 & 0.50 & 0.43 & 12.55 & 28.81 & 7.32 & 16.23 & 64.59 & 64.60 & 69.59 & 66.09 \\
\hline Pb 1.0 g/l & 0.82 & 0.93 & 0.86 & 0.87 & 17.91 & 6.93 & 13.81 & 12.88 & 66.16 & 65.52 & 70.35 & 67.35 \\
\hline $\mathrm{Pb} 1.5 \mathrm{~g} / \mathrm{l}$ & 0.64 & 0.71 & 0.95 & 0.77 & 57.07 & 52.70 & 36.39 & 48.71 & 65.44 & 68.43 & 72.04 & 68.64 \\
\hline Mean & 0.64 & 0.67 & 0.77 & & 29.18 & 29.48 & 19.18 & & 65.39 & 66.18 & 70.49 & \\
\hline $\begin{array}{rr}\text { LSD 5\% } & \text { Conc. } \\
& \text { Time } \\
\text { Conc. } x & \text { Time } \\
\end{array}$ & & $\begin{array}{c}0.0 \\
0 . \\
0 .\end{array}$ & $\begin{array}{l}88191 \\
8171 \\
317 \\
\end{array}$ & & & $\begin{array}{l}3.40 \\
7.66 \\
2.1 \\
\end{array}$ & $\begin{array}{l}955 \\
6841 \\
332 \\
\end{array}$ & & & & $\begin{array}{l}0941 \\
0277 \\
9871 \\
\end{array}$ & \\
\hline $\begin{array}{c}\text { pH } 4 \\
\text { Pb } 0.5 \text { g/l } \\
\text { Pb } 1.0 \text { g/l } \\
\text { Pb } 1.5 \text { g/l } \\
\text { Mean }\end{array}$ & $\begin{array}{l}0.156 \\
0.455 \\
0.319 \\
\mathbf{0 . 3 1 0}\end{array}$ & $\begin{array}{l}0.185 \\
0.322 \\
0.536 \\
\mathbf{0 . 3 4 8}\end{array}$ & $\begin{array}{l}0.175 \\
0.423 \\
0.461 \\
\mathbf{0 . 3 5 3}\end{array}$ & $\begin{array}{l}0.172 \\
0.400 \\
0.439\end{array}$ & $\begin{array}{l}68.777 \\
54.499 \\
78.733 \\
\mathbf{6 7 . 3 3 6}\end{array}$ & $\begin{array}{l}62.960 \\
67.842 \\
64.265 \\
\mathbf{6 5 . 0 2 2}\end{array}$ & $\begin{array}{l}65.090 \\
57.719 \\
69.265 \\
\mathbf{6 4 . 0 2 4}\end{array}$ & $\begin{array}{l}65.609 \\
60.020 \\
70.754\end{array}$ & $\begin{array}{c}7.208 \\
20.715 \\
15.047 \\
\mathbf{1 4 . 3 2 4}\end{array}$ & $\begin{array}{c}8.748 \\
15.512 \\
24.647 \\
\mathbf{1 6 . 3 0 2}\end{array}$ & $\begin{array}{c}8.091 \\
19.514 \\
22.849 \\
\mathbf{1 6 . 8 1 8}\end{array}$ & $\begin{array}{c}8.016 \\
18.580 \\
20.848\end{array}$ \\
\hline $\begin{array}{rr}\text { LSD 5\% } & \text { Conc. } \\
& \text { Time } \\
\text { Conc } x & \text { Time } \\
\end{array}$ & & $\begin{array}{l}0.0 \\
0 . \\
0.3\end{array}$ & $\begin{array}{l}76021 \\
7101 \\
1201 \\
\end{array}$ & & & $\begin{array}{r}3.09 \\
1.0 \\
0.97 \\
\end{array}$ & $\begin{array}{l}122 \\
233 \\
161 \\
\end{array}$ & & & & $\begin{array}{l}1002 \\
1198 \\
1027 \\
\end{array}$ & \\
\hline $\begin{array}{c}\text { pH6 } \\
\text { Pb } 0.5 \text { g/l } \\
\text { Pb } 1.0 \text { g/l } \\
\text { Pb } 1.5 \text { g/l } \\
\text { Mean }\end{array}$ & $\begin{array}{l}0.124 \\
0.263 \\
0.143 \\
\mathbf{0 . 1 7 7}\end{array}$ & $\begin{array}{l}0.143 \\
0.187 \\
0.521 \\
\mathbf{0 . 2 8 4}\end{array}$ & $\begin{array}{l}0.166 \\
0.132 \\
0.097 \\
\mathbf{0 . 1 3 2}\end{array}$ & $\begin{array}{l}0.144 \\
0.194 \\
0.254\end{array}$ & $\begin{array}{l}75.232 \\
73.713 \\
90.449 \\
\mathbf{7 9 . 7 9 8}\end{array}$ & $\begin{array}{l}71.315 \\
81.274 \\
65.298 \\
\mathbf{7 2 . 6 2 9}\end{array}$ & $\begin{array}{l}66.788 \\
86.790 \\
93.503 \\
\mathbf{8 2 . 3 6 1}\end{array}$ & $\begin{array}{l}71.112 \\
80.593 \\
83.083\end{array}$ & $\begin{array}{c}5.758 \\
12.033 \\
6.310 \\
\mathbf{8 . 0 3 3}\end{array}$ & $\begin{array}{c}6.574 \\
9.034 \\
24.017 \\
\mathbf{1 3 . 2 0 8}\end{array}$ & $\begin{array}{l}7.400 \\
6.041 \\
4.509 \\
\mathbf{5 . 9 8 3}\end{array}$ & $\begin{array}{c}6.577 \\
9.036 \\
11.612\end{array}$ \\
\hline $\begin{array}{rr}\text { LSD 5\% } & \text { Conc. } \\
& \text { Time } \\
\text { Conc. } \times & \text { Time } \\
\end{array}$ & & & $\begin{array}{l}1903 \\
6871 \\
0911 \\
\end{array}$ & & & $\begin{array}{l}4.81 \\
1.08 \\
0.67 \\
\end{array}$ & $\begin{array}{l}2232 \\
7322 \\
7161 \\
\end{array}$ & & & $\begin{array}{r}3 . \\
0.8 \\
0 . \\
\end{array}$ & $\begin{array}{l}002 \\
67709 \\
1223 \\
\end{array}$ & \\
\hline $\begin{array}{c}\text { pH } 8 \\
\text { Pb } 0.5 \text { g/l } \\
\text { Pb } 1.0 \text { g/l } \\
\text { Pb } 1.5 \text { g/l } \\
\text { Mean }\end{array}$ & $\begin{array}{l}0.263 \\
0.322 \\
0.959 \\
\mathbf{0 . 5 1 5}\end{array}$ & $\begin{array}{l}0.246 \\
0.351 \\
1.008 \\
\mathbf{0 . 5 3 5}\end{array}$ & $\begin{array}{l}0.131 \\
0.179 \\
0.666 \\
\mathbf{0 . 3 2 5}\end{array}$ & $\begin{array}{l}0.213 \\
0.284 \\
0.878\end{array}$ & $\begin{array}{l}47.428 \\
67.809 \\
36.033 \\
\mathbf{5 0 . 4 2 3}\end{array}$ & $\begin{array}{l}50.856 \\
64.947 \\
32.777 \\
\mathbf{4 9 . 5 2 6}\end{array}$ & $\begin{array}{l}63.792 \\
82.081 \\
55.619 \\
\mathbf{7 0 . 4 9 7}\end{array}$ & $\begin{array}{l}57.359 \\
71.612 \\
41.476\end{array}$ & $\begin{array}{l}12.010 \\
15.071 \\
44.284 \\
\mathbf{2 3 . 7 8 9}\end{array}$ & $\begin{array}{l}11.255 \\
16.510 \\
46.530 \\
\mathbf{2 4 . 7 6 5}\end{array}$ & $\begin{array}{c}6.004 \\
8.273 \\
30.748 \\
\mathbf{1 5 . 0 0 8}\end{array}$ & $\begin{array}{c}9.757 \\
13.285 \\
40.521\end{array}$ \\
\hline $\begin{array}{cc}\text { LSD 5\% } & \begin{array}{c}\text { Conc. } \\
\text { Time }\end{array} \\
\text { Conc. } x & \text { Time } \\
\end{array}$ & & $\begin{array}{c}0.0 \\
0.0 \\
0.5\end{array}$ & $\begin{array}{l}39121 \\
230093 \\
2301\end{array}$ & & & $\begin{array}{l}3.0 \\
1.0 \\
0.7 \\
\end{array}$ & $\begin{array}{l}122 \\
653 \\
861\end{array}$ & & & $\begin{array}{c}3.0 \\
1.0 \\
0.3\end{array}$ & $\begin{array}{l}0988 \\
9998 \\
3983 \\
\end{array}$ & \\
\hline
\end{tabular}




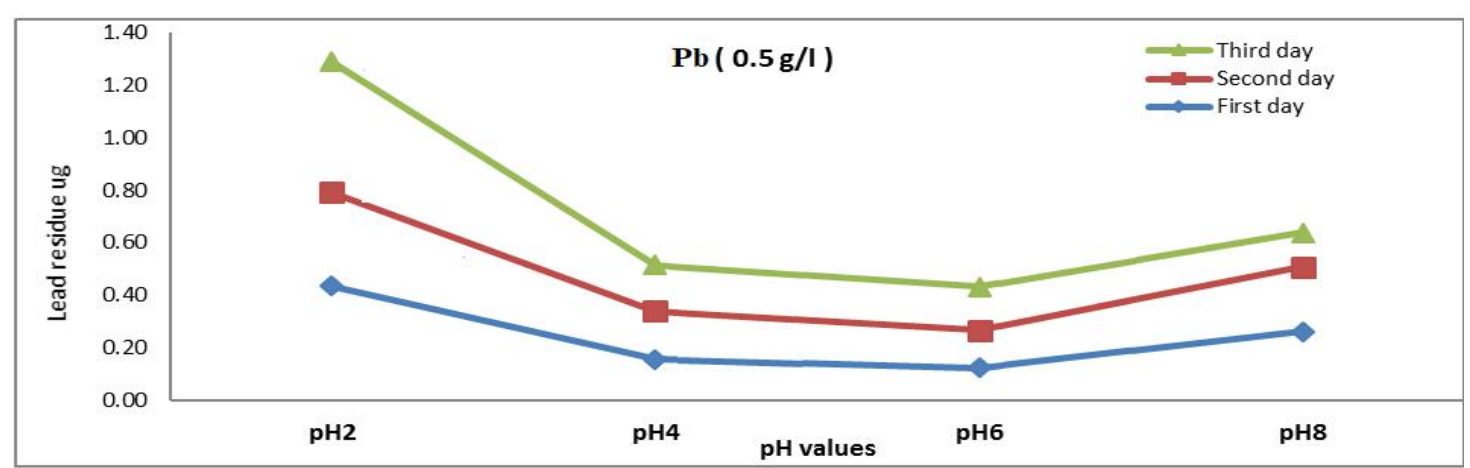

Fig. 1: Effect of Moringa oleifera coagulation protein on participation lead ( $0.5 \mathrm{~g} / \mathrm{l})$ of synthetic raw water during clarification time

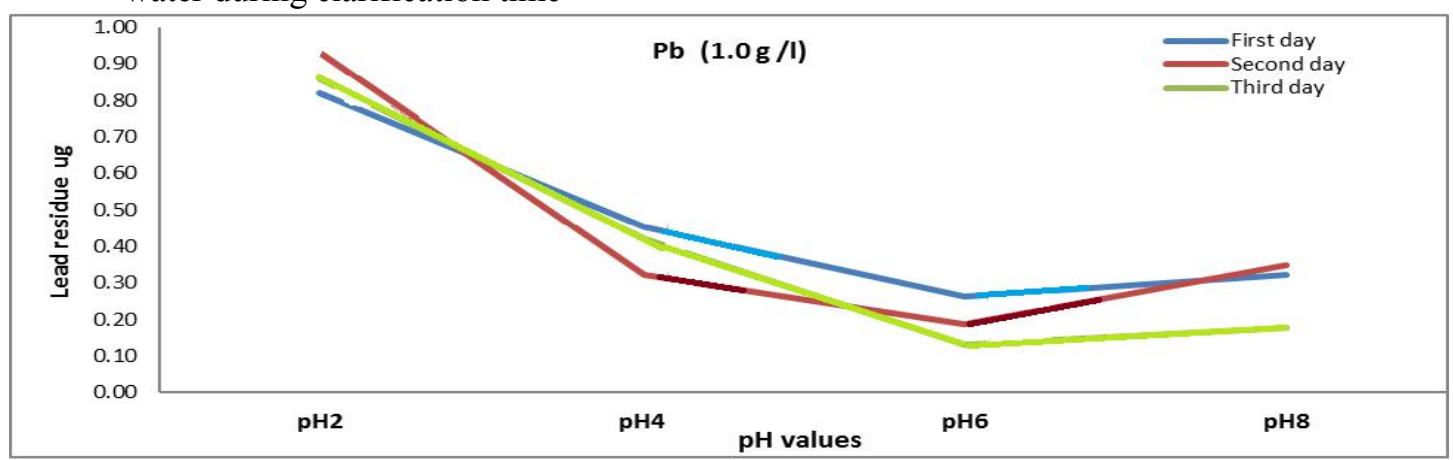

Fig. 2: Effect of Moringa oleifera coagulation protein on participation lead $(1.0 \mathrm{~g} / \mathrm{l})$ of synthetic raw water during clarification time

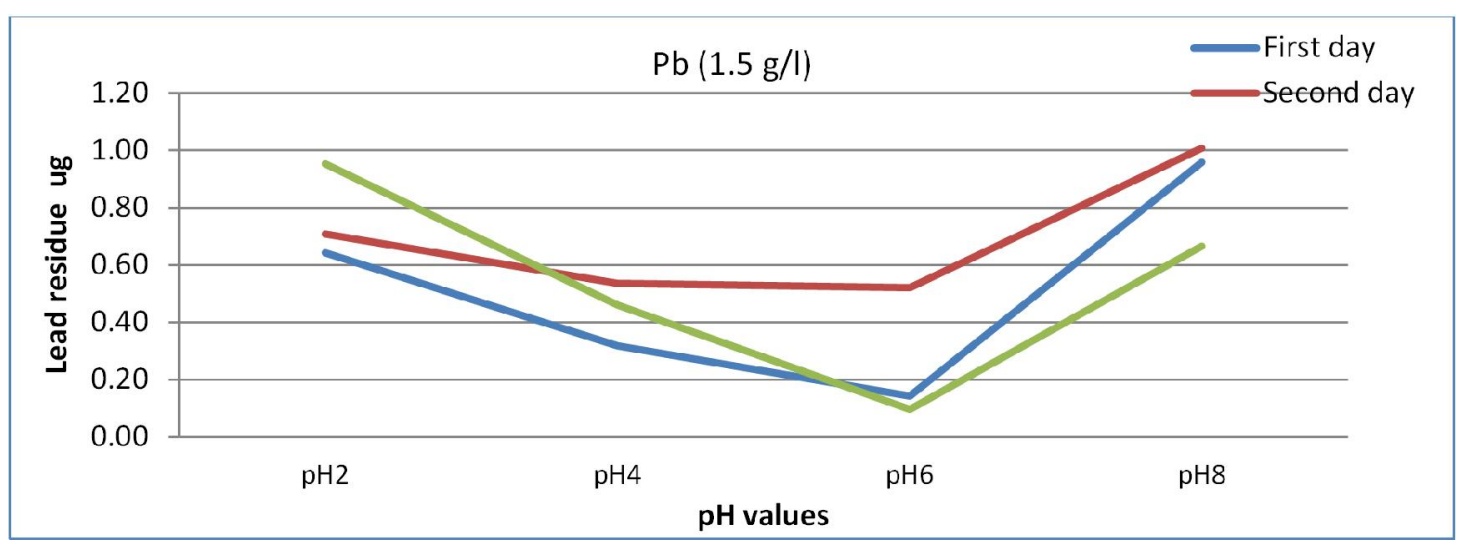

Fig. 3: Effect of Moringaoleifera coagulation protein on participation lead $(1.5 \mathrm{~g} / \mathrm{l})$ of synthetic raw water during clarification time

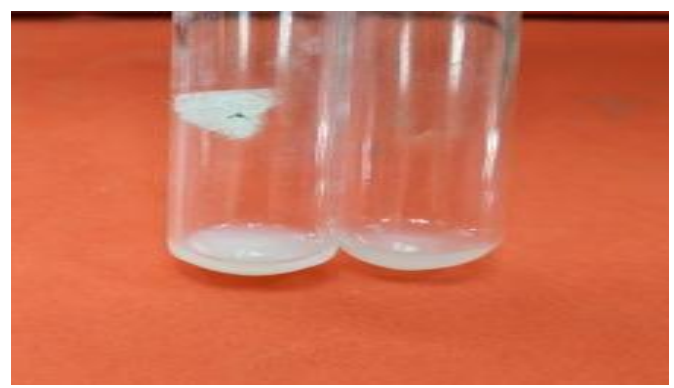

(a)

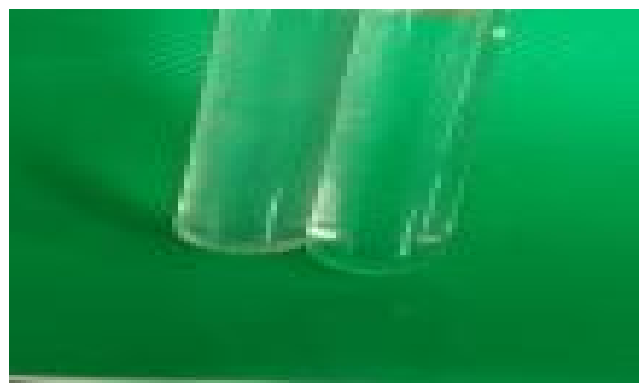

(b)

Fig. 4 (a): Synthetic wastewater before and (b) Sediment forming after coagulation process 


\section{Effect of time on binding of lead to MOCP}

Time is an important parameter to determine the binding efficiency of metals to the protein. The binding efficiency of lead to MOCP was analyzed at different time intervals (1, 2 and 3 days, respectively). The maximal binding was observed at the third day. The lead coagulation increased with increasing the contact time, the maximum removal of lead as is evident from the (Fig. 4). From the Figure it is clear that at 3 days there is maximum removal of lead from the solution beyond which there is no significant change.

The data in Table (1) and Fig. (4), showed effect of the time in precipitation lead in synthetic wastewater. In the end of first day as shown in Fig (4) the amount of lead scored the lowest value in $0.177 \mathrm{ug} / \mathrm{l}$ at $\mathrm{pH} 6$ this value at the same time increasing gradually to $0.31,0.51$ and $0.64 \mathrm{ug} / 1$ at $\mathrm{pH} 4,8$ and 2, respectively. At the end of second day all treatments gave a slightly increase in their levels 0.284 , $0.348,0.535 \mathrm{ug} / \mathrm{l}$ and $0.67 \mathrm{ug} / \mathrm{l}$ at $\mathrm{pH} 6,4,8$ and 2 , respectively.

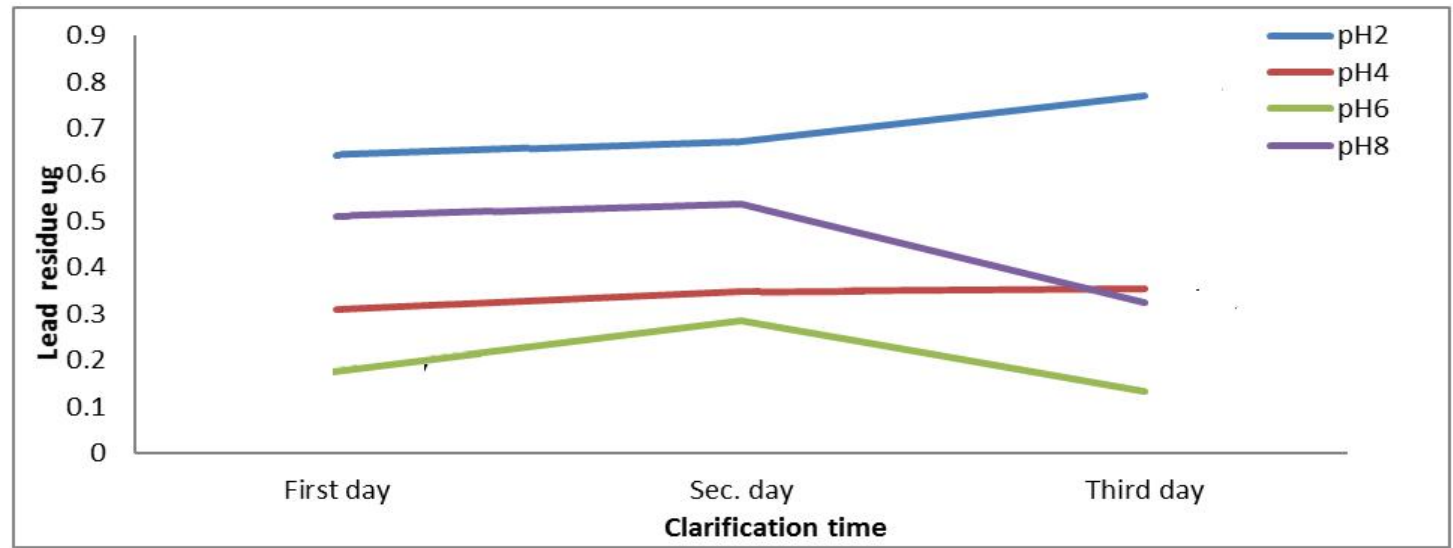

Fig. 5: Effect of time on binding of lead to Moringaoleifera coagulation protein on participation lead of synthetic wastewater

In general, the $\mathrm{pH} 6$ was more effect on binding protein with lead during the clarification times which scored the lowest levels in the three days.

\section{Effect of initial $\mathrm{Pb}(\mathrm{II})$ concentrations}

It is clear that the decreasing in amount of lead gave increasing in the removal lead amount according to the data in Table (1) and Fig (5)

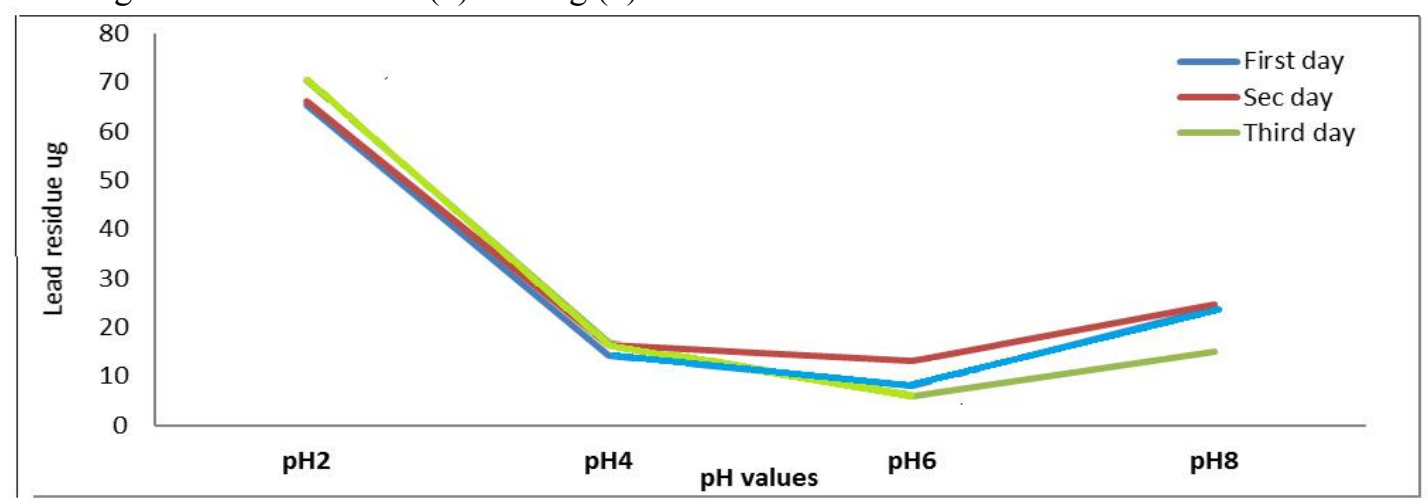

Fig. 6: Effect of heavy metal concentrations on binding to Moringa oleifera coagulation protein in synthetic wastewater

The data shows the lowest concentration of lead $(0.5 \mathrm{~g} / \mathrm{l})$ gave the best results of coagulation process especially at $\mathrm{pH} 6(0.144 \mathrm{ug} / \mathrm{l})$ following by $\mathrm{Pb}$ at $1.0 \mathrm{~g} / \mathrm{l}$ and $1.5 \mathrm{~g} / \mathrm{l}$. 


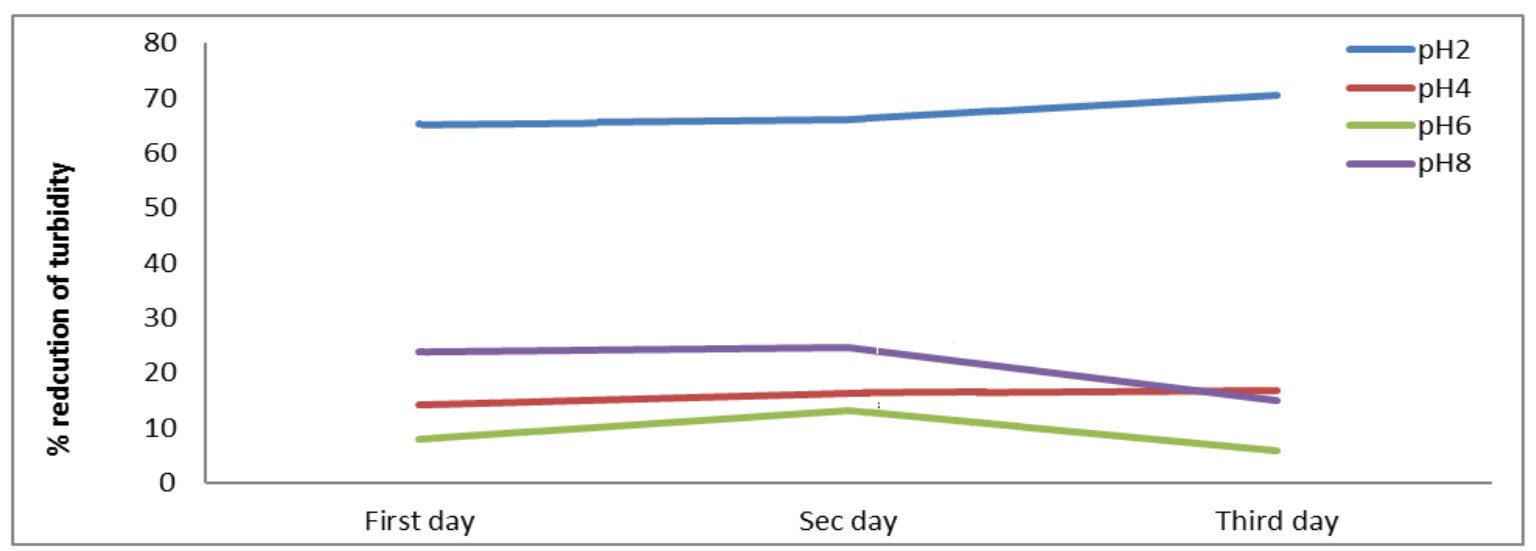

Fig. 7: Effect of time on binding of lead and $\mathrm{pH}$ levels on the percentage of reduction turbidity of synthetic wastewater

\section{Turbidity reduction}

Finally, the Fig (5) shows that the synthetic wastewater was clarifying after adding the stoke of MOCP to contaminated water with lead for three days after adjusting $\mathrm{pH}$ to 6 . These treatments gave the lowest reduction of turbidity $5.93 \%$ that returned to the lowest values of turbidity percentage.

\section{Coagulation kinetic}

According to equation (1) and (2), the coagulation kinetic was calculate for the sedimentation factor $(K)$ of moringa seeds powder with lead $(\mathrm{g})$ as showing the next following

$\mathrm{W}_{\mathrm{f}}=0.01838(\mathrm{~g})$ of dry weight

$\mathrm{W}_{\mathrm{i}}=0.01246(\mathrm{~g})$ of dry weight

$\mathrm{T}=$ three days $\quad K=\Delta \mathrm{W} / \Delta \mathrm{t}$

$K=[(0.01838-0.01246) / 3]=0.00197(\mathrm{~g})$ sediment $/$ day that mean one gram of MOCP gave 1.97 $\mathrm{mg} /$ day sediment containing lead.

If synthetic wastewater containing $0.5 \mathrm{~g} / 1$ lead with NTU less than 50 (Jahn, 1986) using the above equation : $\mathrm{W}_{\mathrm{f}}=0.166(\mathrm{~g})$ of dry weight $\mathrm{W}_{\mathrm{i}}=0.5(\mathrm{~g})$ of dry weight

$\mathrm{T}=$ three days $\quad K=\Delta \mathrm{W} / \Delta \mathrm{t}$

$K=[(0.5-0.166) / 3]=0.1113(\mathrm{~g})$ lead/day that mean one gram of MOCP can binding with $0.1113 \mathrm{~g}$ with lead

\section{Moringa olifera particles characterization}

\section{Energy dispersive X-ray (EDX)}

The chemical analysis using EDX technique consists of detection of those protons using a solid detector $\mathrm{Si}-\mathrm{Li}$ (detection by energy dispersion). The energy of these photons, $\mathrm{X}$, is characteristic of its atoms. A line spectrum (peak) is obtained, each corresponding to the photons $\mathrm{X}$ of a given energy, representing a given element. The intensity of the characteristic lines is proportional to the concentration of the element in the analytical volume. This analysis is quantitative (Fig. 6c and 7c). However, there is a factor of correction depending on the experimental parameters (energy of the incidental beam, its angle) and the sample composition. Thus, only a semi-quantitative analysis is considered. The detection limit is situated at the concentrations of $0.1-1 \%$ (for elements having average or light atomic weight with the exception of unfavorable superposition of characteristic peaks). The detector allows detection of light elements (C, O, Si, N) (Fig.8c).

The EDX result of raw and coagulated lead with M. oleifera presented in Tables 2 and 3 showing the differences between the amount of carbon, oxygen, silica and $\mathrm{Pb}$ in the samples. The sample with the highest amount of carbon and the least amount of oxygen is said to be the most effective. The meaning of this is that, the higher the amount of carbon present in the sample, the lower is the amount of oxygen. According to the Tables 2 and 3, it was observed that the coagulated lead by M. Oleifera has the highest amount of carbon by weight (59.31\%) and (59.97\%) by atom and the lowest amount of 
oxygen followed by raw M. Oleifera has the least percentage by weight of carbon. The implication of this is that only the sample that is rich in carbon content can be an efficient adsorbent for the removal of dyes, heavy metals and other organic pollutants from aqueous solution.

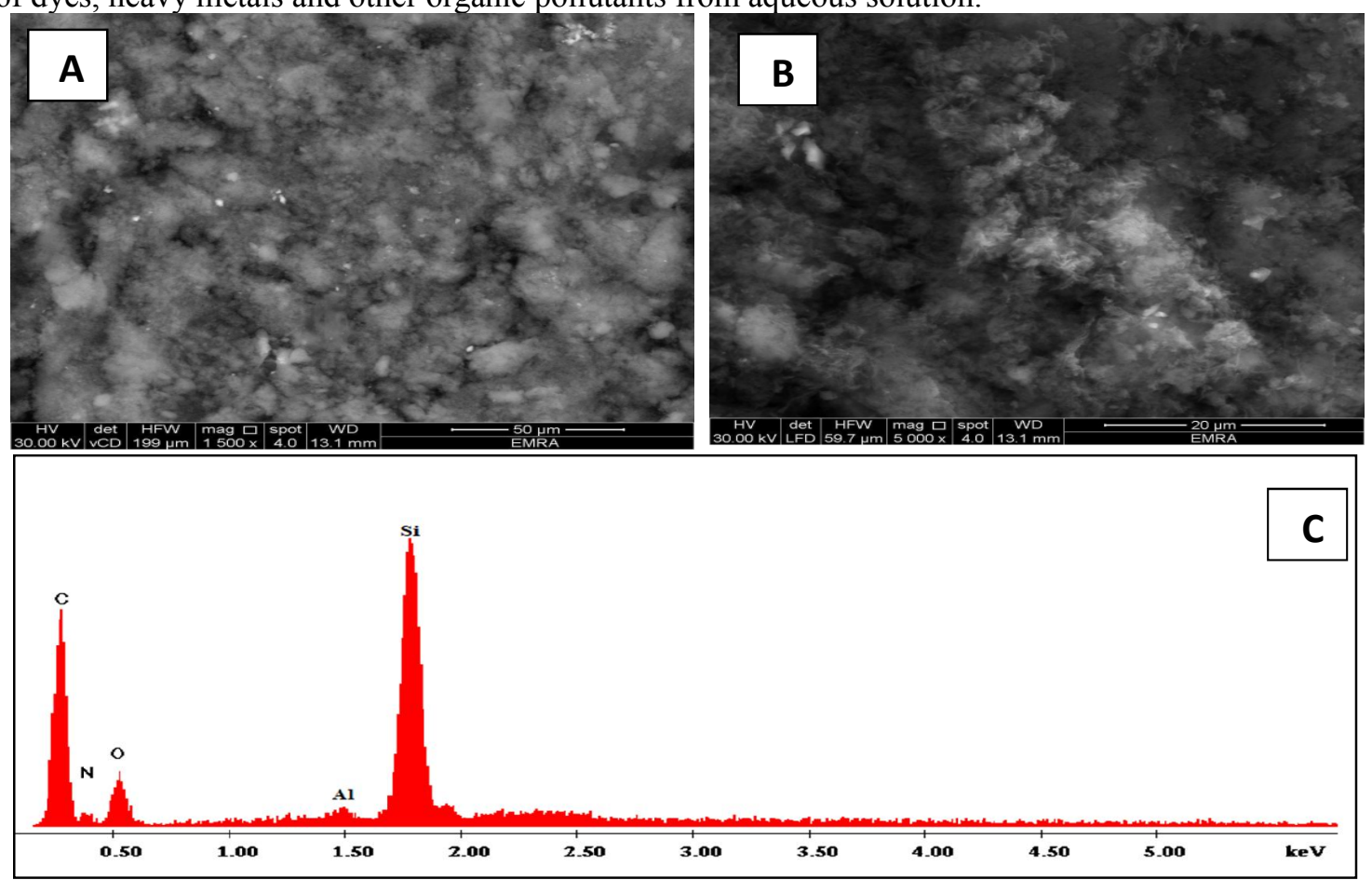

Fig. 8: The SEM micrographs and Energy dispersive X-ray (EDX) of a raw Moringa oleifera (magnification 1000) and energy
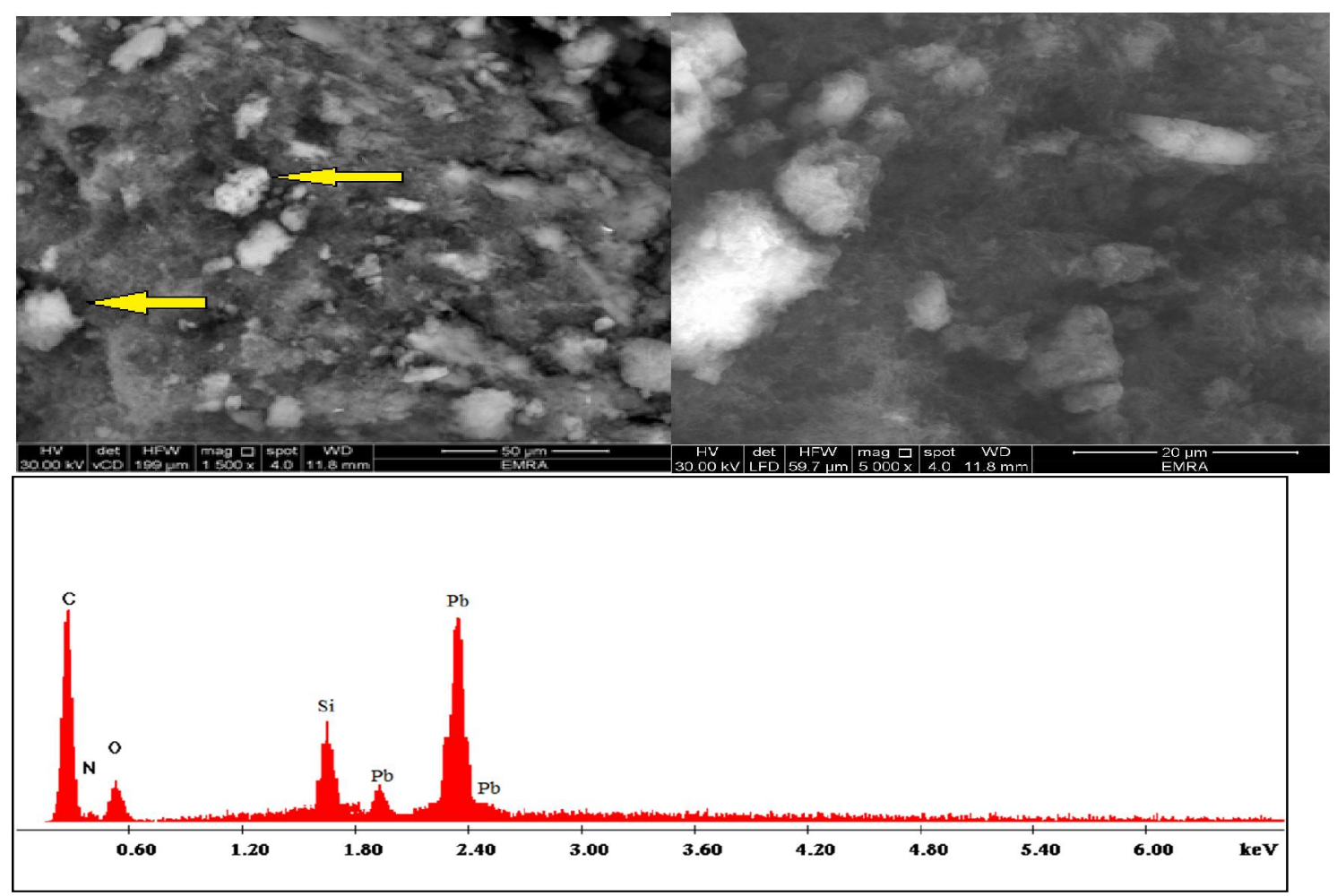

Fig. 9: The SEM micrographs and Energy dispersive X-ray (EDX) of a raw Moringa olefera coagulated with lead granules (Yellow arrow )(magnification 1000) and energy 
Table 2: EDX result of Moringa olifera

\begin{tabular}{ccccccc}
\hline Element & Wt \% & At \% & K-ratio & $\boldsymbol{Z}$ & $\boldsymbol{A}$ & $\boldsymbol{F}$ \\
\hline $\mathbf{C}$ & 59.31 & 65.57 & 0.3586 & 1.0066 & 0.6005 & 1.0003 \\
$\mathbf{N}$ & 12.95 & 12.27 & 0.0138 & 0.9992 & 0.1069 & 1.0005 \\
$\mathbf{O}$ & 26.34 & 21.86 & 0.0353 & 0.9925 & 0.1351 & 1.0000 \\
$\mathbf{A l}$ & 0.4 & 0.22 & 0.0151 & 0.8001 & 1.0024 & 1.0001 \\
$\mathbf{S i}$ & 1.01 & 0.08 & 0.0192 & 0.8309 & 1.0378 & 1.0000 \\
Total & 100.00 & 100.00 & & & & \\
\hline
\end{tabular}

Table 3: EDX result of Moringa olifera coagulated with lead

\begin{tabular}{ccccccc}
\hline Element & Wt \% & At \% & K-ratio & $\boldsymbol{Z}$ & \multicolumn{1}{c}{$\boldsymbol{A}$} \\
\hline $\mathbf{C}$ & 59.97 & 65.57 & 0.3586 & 1.0066 & 0.6005 & 1.0003 \\
$\mathbf{N}$ & 12.42 & 11.88 & 0.0138 & 0.9992 & 0.1069 & 1.0005 \\
$\mathbf{O}$ & 24.30 & 21.30 & 0.0353 & 0.9925 & 0.1351 & 1.0000 \\
$\mathbf{S i}$ & 1.11 & 0.14 & 0.0122 & 0.8309 & 1.0378 & 1.0000 \\
$\mathbf{P b}$ & 1.34 & 0.42 & 0.0212 & 0.8305 & 1.0381 & 1.0001 \\
$\mathbf{A l}$ & 0.86 & 0.08 & 0.0101 & 0.8001 & 1.0024 \\
Total & 100.00 & & & & & \\
\hline
\end{tabular}

\section{Pore structure analysis}

The pore characteristics of the Moringa oleifera seed mainly depend on the raw materials conditions. The prepared MOS had a surface area of $20.4091 \mathrm{~m}^{2} / \mathrm{g}$, a total pore volume of 0.0167454 $\mathrm{cc} / \mathrm{g}$, Average Pore Size $1.64098 \mathrm{~nm}$ (Microporous $<2 \mathrm{~nm}$ ). Moreover, the Average Pore Size (1.64098 $\mathrm{nm}<2 \mathrm{~nm}$ ) confirmed the (Microporous structure of the MOS, which favored the adsorption of low-to medium-sized molecules (Zazycki et al., 2018; Ahmed and Hameed, 2018). In general, natural materials with small surface areas are expected, as in the case of moringa seeds, and therefore the functional groups present on their surfaces characterize the adsorption capacity.

\section{Scanning electron micrographs of Moringa oleifera}

Figs. 8 and 9show SEM images of the Moringa oleifera seeds used to analyze the morphologies of the studied adsorbent. Fig. 8 shows that the material formed by MOS are both spherical and villous, moreover, the villus was presented as Nanoscale. The villous structure covered on the MOS was much thin. It can be speculated that the spherical structure and Nanoscale villus plays an important role in the coagulation and adsorption process (Gan et al., 2016). It is observed also that, the material exhibits a heterogeneous and relatively porous matrix. The spaces available facilitate the adsorption process because they provide a high internal surface area. The same conclusion was reported by Araújo et al., 2010. The author also explains that this structure facilitates the ionic adsorption processes due to the interstices and more importantly, the presence of the protein component of the seed. The porous nature of this material can also be observed in the data obtained with the BET analysis. The results also indicate that there was a layer covering the surfaces of the Moringa oleifera seed, possibly lead ions (Fig.9). A similar type of other adsorbent spectra has also been reported by other scientists, during different research findings (Gustavo et al., 2018; Temesgen et al., 2018).

\section{Protein binding heavy metals}

According to the data in fig. (10) The coagulating agent in Moringa seed has been identified as a protein with a molecular mass of about $6.5 \mathrm{kDa}$ and the isoelectric point is above $\mathrm{pI} 10$. Amino acid analysis and sequencing showed a total of 60 residues and this peptide has been reported to the protein database and given the name MO2.1 (SwissProt ID:P24303) Gassenschmidt et al., (1995).

As showing in fig. (10) (EMBL:CAC69951.1 database) MOP2.1 and MOP 2.2 the red letters is the most charged area which responsible for coagulation because it was containing many positive charge that containing 7 arginines, 1 histidine and 14 glutamine residues which responsible for coagulation process. The sequence in Fig. (10) showing that amino acid residues varied in their charges, 7 arginine, 1 histidine (positive charge) $13.3 \%, 14$ glitamine $23.33 \%, 4$ glycine, 7 proline, 1 aspartic acid (1.6\% negative charg), 1 phenylalanine, 4 cystein, 3 leucine, 2 asparagine, 2 isoleucine, 4 serine, 2 alanine, 4 valine, 1 tyrosine, 1 methionine and 2 therionine.It has been shown that glutamine-rich regions in proteins cause their aggregation. Also, homologous of amino acids showed in the yellow box in fig. 
(10) between $2 \mathrm{~S}$ albumin residues, mabinlin and $\mathrm{MOP}_{2.1,2.2}$ whereas, the identical residues appear in yellow box recorded $31.66 \%, 13.10 \%$ and $22.35 \%$ from $2 \mathrm{~S}$ albumin residues, mabinlin and $\mathrm{MOP}_{2.1,2.2}$, respectively. Moreover, the highly similar residues were observed in the bold litters about 15\%, 6.02 and $10.5 \%$ for $2 \mathrm{~S}$ albumin residues, mabinlin and $\mathrm{MOP}_{2.1,2.2}$, respectively.

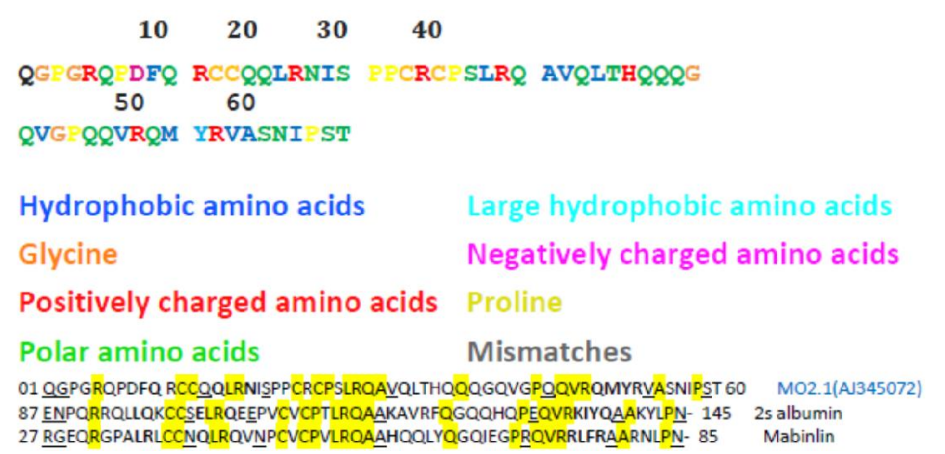

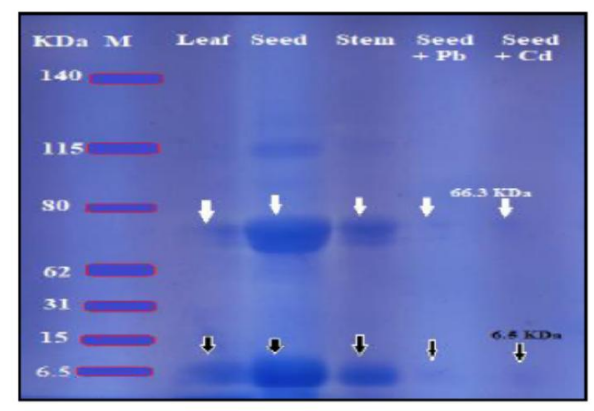

Fig. 10: Amino acids residues in MOP proteins shows regions cause aggregation and SDS PAGE gel electrophoresis of moringa proteins isolated from leaf, seed and stem also, seed protein binding with lead

The data in fig. (10) a sequence of $2 \mathrm{~S}$ albumin that in moringa seeds, it has 25 glutamine residues (15.5\%), 17 arginine residues (10.5\%) that causes positive charge on the service of protein that responsible for coagulation. Also, the molecular mass of the purified protein was determined to be approximately $66.3 \mathrm{kDa}$ on a $15 \%$ SDS-PAGE as shown (Fig. 10) in the four lans (seed, leave, stem and seed binding with lead).

\section{Discussion}

The MO seed powder has been termed as potential heavy metal removing agent due to its oxygen and nitrogen donating carboxylate and amino groups. The adsorption of metals using MO is limited to the adsorption surface. This is because MO is a cationic polyelectrolyte of short chain and low molecular weight. The mechanism that brings about adsorption of heavy metals is through the positive metal ions that forms a bridge among the anionic polyelectrolyte and negatively charged protein functional groups on the colloidal particle surface. There is formation of complexes with the heavy metals and the organic matter of MO seeds such as proteins. Due to hydrophilic character, several hydrogen bonds are formed among polyelectrolyte and water molecules. Polyelectrolyte coagulant aid have structures consisting of repeating units of small molecular weight forming molecules of colloidal size that carry electrical charges or ion stable groups that provide bonding surface for the flocs. Adsorption describes attachment of ions and molecules from seed protein by means of specific mechanism. Metal ions in coagulation react with proteins and destroy them in water. Metal adsorption occurs due to the high protein content of the seeds. The flocculation activities of MO seeds are based on the electrostatic patch charge mechanism. Studies have shown that seeds have the capability to adsorb metal cations and attract highly toxic compounds.

The probable reason of $\mathrm{pH} 6$ as its optimal $\mathrm{pH}$ is because the amino acids present in M. Oleifera (cationic coagulant) get ionized and produce carboxylate and $\mathrm{H}+$ charge which attract colloidal particles in the medium which get neutralized and settle down as flocs. Since this produces carboxylate ions after ionization we can observe that the water becomes more alkaline (Dabigengesere et al., 1995). The reason behind high turbidity reduction at an optimal dosage of coagulant is because as soon as the $M$. Oleifera concentration exceeds the optimum dosage, turbidity increases because all colloids have already been neutralized and have got precipitated at the optimum dosage. Thus, if high dosage is used, the excess coagulants will simply get added and cause turbidity in water as they did not interact with oppositely charged colloidal particles as those particles have already been flocculated earlier.

Increase in $\mathrm{pH}$ than 6 caused a decrease in lead removal (Fig. 7) suggesting that the lead removal reaction involves electrostatic interaction (Krishnan and Anirudhan, 2003). At high pH level (pH8) some ionic strength formed in raw water like $\mathrm{Na}^{+}, \mathrm{k}^{+}$can compete for binding sites with $\mathrm{Pb}^{2+}$ ions on 
the polyelectrolytes and hence reduce lead removal. Furthermore, $\mathrm{Pb}^{2+}$ ions form stable complexes with chloride ions, which inhibit interaction between $\mathrm{Pb}^{2+}$ and the polyelectrolyte sites

Fig. 6 shows that the $\mathrm{pH}$ on turbidity removal using M.O protein. As the $\mathrm{pH}$ increased the percentage of turbidity removal decreased. The highest turbidity removal using M.O- was observed to occur at $\mathrm{pH} 6$ with a percentage of turbidity removal $95.5 \%$ (4.53\% reduction) while it is clear that $\mathrm{pH}$ changes do alter the final turbidity in terms of the overall removal, the changes are not appreciable and suggest that there is no reason to consider using Phaseolus vulgaris and Strychnos potatorum at a $\mathrm{pH} 5$ other than neutral.

To characterize the lead binding to MOCP parameters like $\mathrm{pH}$, time, and concentration of the lead were taken in our study as described under methods and the metal binding was estimated by EDTA complex metric method. The maximum binding was detected at $\mathrm{pH} 6$ (Fig. 2). Since pH 6.0 was found to be optimal $\mathrm{pH}$ for binding, this was used in further separate experiments.

Time is an important parameter to determine the binding efficiency of metals to the coagulation. The binding efficiency of lead to MOCP was analyzed at different time intervals (1, 2 and 3 days, respectively). The maximal binding was observed at 3 days. The lead binding protein increased with increasing the contact time, the maximum removal of lead as is evident from the (Fig. 6). From the figure it is clear that at 3 days there is maximum removal of lead from the solution beyond which there is no significant change. In this concern, the biosorption is rapid in the initial stage, and then increases steadily to reach equilibrium. This can be attributed to the availability of a large number of vacant sorption sites for biosorption during the initial stage. With the increase in contact time, these sites become saturated. In this concern, a reduction in some heavy metals like $\mathrm{Ni}^{2+}$ biosorption occurred due to the decrease in the number of vacant sites after certain contact time (Gustavo et al., 2018).

In this regard (DePace et al., 1995; Stott et al., 1995) explained the protein oligomerization was formed by the formation of $\beta$-pleated sheets held together by hydrogen bonds. Also, the high density of glutamine residues in MO2.1 could favor floc formation through hydrogen bonding among proteins coating the particles. Further investigations are necessary to assess the importance of this mechanism in the flocculation process involving MO2.1 (Stott et al., 1995). The same results were observed by Perutz et al., (1994) who found that glutamine-rich regions in proteins cause their aggregation.

Finally, we concluded that although the performance of the coagulants was satisfactory and pilot plants have been designed, the economic feasibility analysis to design large scale treatment plants still needs to be carried out. Since the natural coagulant by itself is inefficient in treating water of very high turbidity, the authors propose that the further research can be carried out by mixing the natural occurring coagulants with synthetic ones and studying the performance of the resulting coagulant.

\section{Declarations of interest:}

The authors declare that they have no conflict of interest.

\section{References}

Abdull, R., F. Ahmad, M.D. Ibrahim and S.B. Kntayya, 2014. Health benefits of Moringa oleifera. Asian Pac. J. Cancer Prev. APJCP, 15 (20): 8571-8576.

Adelaja, O., I. Amoo and D. Aderibigbe, 2011. Biosorption of Lead ( II ) Ions from Aqueous Solution Using Moringa oleifera Pods. Archives of Applied Science Research 3 (6): 50-60.

Ahmad, M.A. and R. Alrozi, 2011. Removal of malachite green dye from aqueous solution using rambutan peel-based activated carbon: equilibrium, kinetic and thermodynamic studies. Chem. Eng. J. 171(2):510-516.

Ahmed, M. J. and B.H. Hameed, 2018. Adsorption behavior of salicylic acid on biochar as derived from the thermal pyrolysis of barley straws. Journal of Cleaner Production, 195:1162-1169.

Akhtar, M., S.M. Hasany, M. Bhanger and S. Iqbal, 2007. Sorption potential of Moringa oleifera pods for the removal of organic pollutants from aqueous solutions. J. Hazard Mater., 141 (3): 546-556.

Andrew J. H., P. Vale, J.Whelan, L. Alibardi and P. Campo, 2018. Impacts of coagulation-flocculation treatment on the size distribution and bioavailability of trace metals $(\mathrm{Cu}, \mathrm{Pb}, \mathrm{Ni}, \mathrm{Zn})$ in municipal wastewater. Water Research, 128, 120-128. 
Araújo, C.S.T., V.N. Alves, H.C. Rezende, I.L.S. Almeida, R.M.N. Assunç ao, C.R.T. Tarley, M.G. Segatelli and N.M.M Coelho, 2010. Characterization and use of Moringa oleifera seeds as biosorbent for removing metal ions from aqueous effluents. Water Sci. Technol. 62: 2198-2203.

Chang, J., C. Dong and S. Shen, 2019. The lead contaminated land treated by the circulation-enhanced electro kinetics and phytoremediation in field scale. Journal of Hazardous Materials, 368: 894-898.

Coldebella, P.F., M.R. Fagundes-Klen, L. Nishi, K.C. Valverde, E.B. Cavalcanti, A. dos Santos, O. Aparecida and R. Bergamasco, 2017. Potential effect of chemical and thermal treatment on the Kinetics, equilibrium, and thermodynamic studies for atrazine biosorption by the Moringaoleifera pods. Can. J. Chem. Eng., 95 (5): 961-973.

Dabigengesere, N., K. S. Narasiah and B. G. Talbot, 1995. Active agents and mechanism of coagulation of turbid water using Moringa oleifera. Water Res., 29: 703-710.

De Carvalho, H.P., J. Huang, J. Ni, M. Zhao, X. Yang and X. Wang, 2015. Removal of Acid Black 1 and Basic Red 2 from aqueous solutions by electrocoagulation/Moringa oleifera seed adsorption coupling in a batch system. Water Sci. Technol., 72 (2): 203-213.

Déborah, L., B. Villaseñor, D. Pablo, S. Astudillo, D.R.O. Jorge and R.B. Erick, 2018. Wastewater treatment using Moringaoleifera Lam seeds: A review. Journal of Water Process Engineering, 23, 151-164.

DePace, A. H., A. Santoso, P. Hillner and J.S. Weissman, 1998. A criticalrole for amino-terminal glutamine/asparagine repeats in the formation and propagation of a yeast prion. Cell 93:12411252.

Duncan, D.B., 1955. Multiple range and multiple "F-test". Biometrics, 11: 1-42.

Figueira, V., I. Vaz-Moreira, M. Silva and C. M. Manaia, 2011. Diversity and antibiotic resistance of Aeromonas sp. In drinking and waste water treatment plants. Water Res., 45: 5599-5611.

$\mathrm{Fu}, \mathrm{W}$. and Z. Huang, 2018. Magnetic dithio carbamate functionalized reduced graphene oxide for the removal of $\mathrm{Cu}$ (II), $\mathrm{Cd}$ (II), $\mathrm{Pb}$ (II), and $\mathrm{Hg}$ (II) ions from aqueous solution: Synthesis, adsorption, and regeneration. Chemosphere, 209: 449-456.

Gan, M., Z. Song, S. Jie, J. Zhu, Y. Zhu and X. Liu, 2016. Biosynthesis of bifunctional iron oxyhydrosulfate by Acidithiobacillus ferroxidans and their application to coagulation and adsorption. Materials Science and Engineering: C 59: 990-997.

Gassenschmidt, U., D.K. Jany, B. Tauscher and H. Niebergall, 1995. Isolation and characterization of a flocculating protein from Moringa oleifera Lam. Biochem. Biophys. Acta, 1243: 477-481.

Guo, B., H. Yu, B. Gao, H. Rong and S. Zhao, 2015. Coagulation performance and floc characteristics of aluminum sulfate with cationic polyamidine as coagulant aid for kaolin-humic acid treatment. Colloids and Surfaces A: Physicochemical and Engineering Aspects, 481: 476-484.

Gustavo. A.P.M, P.P. Michele, R.T.S.Tássia, M. F.Silva and B. Rosângela, 2018. Obtaining drinking water using a magnetic coagulant composed of magnetite nanoparticles functionalized with Moringa oleifera seed extract. Journal of Environmental Chemical Engineering, 6, 4084-4092.

Jabłońska B., 2018. Water consumption management in polyethyleneterephthalate(PET) bottles washing process via wastewater pretreatment and reuse. Journal of Environmental Management, 224, 215-224.

Jafari, A. and A.H. Mahvi, 2015. Reactive dyes (R. Blue and R. Red) removal by a natural coagulant: Moringa oleifera. Environ. Eng. Manag.J. (EEMJ), 14 (10).

Khorsand, M., S. Dobaradaran and E. Kouhgardi, 2017. Cadmium removal from aqueous solutions using Moringa oleifera seed pod as a biosorbent. Desalination Water Treat.,71: 327-333.

Kongarapu, R. J., A.K. Nayak, M.U. Khobragade and A. Pal, 2018. Surfactant bilayer on chitosan bead surface for enhanced Ni (II) adsorption. Sustain. Mat. Technol. 17, e00077

Krishnan, K. A. and T. S. Anirudhan, 2003. Removal of cadmium (II) from aqueous solutions by steamactivated sulphurated carbon prepared from sugar-cane bagasse pith: Kinetics and equilibrium studies. Water SA., 29: 147-156.

Laemmli, U. K., 1970. Cleavage of Structural Proteins during the Assembly of the Head of Bacteriophage T4 Nature (227): 680-685.

Li, L., C. Zhu, C. Xie, C. Shao and N. Gao, 2018. Kinetics and Mechanism of Pseudoanabaena Cell Inactivation, 2-MIB Release and Degradation under Exposure of Ozone, Chlorine and Permanganate; Water Research, In press, accepted manuscript, Available online 10 October. 
Liang, Y. L., E. C. K., Tamara, C. R. S. Lucas, A. M. B. Philip and R. H. William, 2019. Effects of ferricsulfateand polyaluminum chloride coagulation enhanced treatment wetlands on Typha growth, soil and water chemistry. Science of The Total Environment, 648:116-124.

Maina. I.W., V. Obuseng and F. Nareetsile, 2016. Use of Moringa oleifera (moringa) seed pods and scleroca ryabirrea (Morula) nut shells for removal of heavy metals from wastewater and borehole water. J. Chem.

Malati, M. A., 1999. Experimental Inorganic/Physical Chemistry: An Investigative, Integrated Approach to Practical Project Work (Horwood Series in Chemical Science). Albion/Horwood Pub. p. 20. ISBN 1-898563-47-0.

Masters, N., A. Wiegand, W. Ahmed and M. Katouli, 2011. Escherichia coli virulence genes profile of surface waters as an indicator of water quality. Water Res., 45: 6321-6333.

Obuseng, V., F. Nareetsile and H.M. Kwaambwa, 2012. A study of the removal of heavy metals from aqueous solutions by Moringa oleifera seeds and amine-based ligand 1, 4-bis [N, N-bis (2-picoyl) amino] butane. Anal. Chim.Acta, 730: 87-92.

Perutz, M.F., T. Johnson, M. Suzuki and J.T. Finch, 1994. Glutamine repeats as polar zippers: their possible role in inherited neuro-degenerative diseases. Proc. Natl. Acad. Sci. USA 91:5355-5358

Reck, I.M., R.M. Paixão, R. Bergamasco, M.F. Vieira and A.M.S. Vieira, 2018. Removal of tartrazine from aqueous solutions using adsorbents based on activated carbon and Moringa oleifera seeds. Journal of Cleaner Production, 171: 85-97.

Reddy, S., R. Konada, V. Kumar, M. N. V. Prasad, and N.S. Kumar, 2017. Moringa oleifera (Drumstick Tree) Seed Coagulant Protein (MOCP) Binds Cadmium - Preparation and Characterization of Nanoparticles. The Euro Biotech Journal 1 (4): 285-92.

Robbins, J.A., 1973. Determination of recent sedimentation rates in Lake Michigan using pb-210. Acta, 1975, 89: $285-304$.

Shan, T.C., M. Al Matar, E.A. Makky and E.N. Ali, 2017. The use of Moringa oleifera seed as a natural coagulant for wastewater treatment and heavy metals removal. Appl. Water Sci., 7 (3): 1369-1376.

Souza dos Santos, B., E. Eyng, P.R. Stival Bittencourt, L. MantovaniFrare, ÉderLisandro de Moraes Flores and M. Budke Costa, 2016. Electro-flocculation associated with the extract of Moringa oleifera Lam as natural coagulant for the removal of reactive blue 5G dye. Acta Sci. Technol., 38 (4).

Steel, R. D. G. and J. H. Torrie, 1980. Principles and procedures of statistics. New York: McGraw-Hill.

Stott, K., J.M. Blackburn, P.J.G. Butler and M. Perutz, 1995. Incorporation of glutamine repeats makes protein oligomerize: implication sfor neurodegenerative diseases. Proc. Natl. Acad. Sci. USA 92: 6509-6513.

Tavares, F.O., L. A. de Moraes Pinto, F.d.J. Bassetti, M.F. Vieira, R. Bergamasco and A.M.S. Vieira, 2017. Environmentally friendly biosorbents (husks, pods and seeds) from Moringa oleifera for $\mathrm{Pb}$ (II) removal from contaminated water. Environ.Technol., 1-11.

Taylor, N. G. H., D. W. Verner-Jeffreys and C. Baker-Austin, 2011. Aquatic systems: maintaining, mixing and mobilizing antimicrobial resistance. Trend. Ecol. Evol., 26: 278-284.

TemesgenG.K, S.D. Alemayehu, A. Mengistie, T.T.N. Mathew and M. Nindi, 2018. Physics and Chemistry of the Earth, Parts A/B/C Available online 8 August In Press,

WHO, http://www.who.int/water_sanitation_health/diseases/burden/en/index.html\#, recently accessed on $26^{\text {th }}$ February (2012).

Zazycki, M.A, M. Godinho, D. Perondi, E. L. Foletto, G.C. Collazzo and G.L. Dotto, 2018. New biochar from pecan nutshells as an alternative adsorbent for removing reactive red 141 from aqueous solutions. Journal of Cleaner Production, 171: 57-65. 